\title{
SOCIAL HOSTS AND DRUNKEN DRIVERS: A DUTY TO INTERVENE?
}

\section{HILARY RAY WEINERT $\dagger$}

A man drives a friend home and is invited in for a drink. The host, his wife, and the guest drink and talk for a few hours, until the guest decides to go home. The host walks the guest out to the car. While driving home, the guest loses control of his car and collides with a car traveling in the opposite direction. The driver of the other car is seriously injured. A blood test administered after the accident indicates that the guest is extremely intoxicated.

Are the hosts responsible for this accident? Should they be held liable for the damages sustained by the innocent third party? Historically, courts have been unwilling to impose liability on social hosts for the acts of their intoxicated guests. ${ }^{1}$ Yet, in a recent case involving facts similar to those above, the New Jersey Supreme Court held hosts liable for injuries caused by a guest's intoxicated driving. ${ }^{2}$

This Comment considers the reasoning behind courts' actions in this area and develops a new approach to the analysis of social-host liability. Part I of the Comment briefly discusses a number of policy considerations and concludes that social-host liability seems appropriate for at least some situations. The second part of the Comment analyzes the three theories on which courts have based social-host liability in the past: extensions of state dramshop acts, which impose civil liability on

† Sc.B. 1980, Brown University; J.D. Candidate, 1986, University of Pennsylvania. The author wrote this Comment while a student at the University of Pennsylvania Law School.

1 See generally Note, Social Host Liability for Injuries Caused by the Acts of an Intoxicated Guest, 59 N.D.L. REv. 445, 451-55 (1983) (discussing cases that refused to extend dramshop-act liability to social hosts).

${ }^{2}$ See Kelly v. Gwinnell, 96 N.J. 538, 476 A.2d 1219 (1984). According to the record in Kelly, Donald Gwinnell drove his friend Joseph Zak home. He then spent an hour or two visiting with the Zaks and had several drinks. Zak walked him out to his car and watched him depart; a short time later, Zak telephoned Gwinnell's home to determine whether he had arrived safely. As Zak then learned, Gwinnell had been involved in a head-on collision with the plaintiff. Gwinnell and the Zaks claimed that he had consumed only two or three drinks, but the plaintiff alleged that the blood alcohol test administered to Gwinnell after the accident showed that he had consumed the equivalent of thirteen drinks. See id. at 541, 476 A.2d at 1220.

The fate of the Kelly decision may not yet be complete; a bill recently introduced in the New Jersey legislature would nullify the effect of the decision by insulating social hosts from liability. See Sullivan, Jersey Hosts Keeping Drunks From Driving, N.Y. Times, Dec. 30, 1984, § 1, at 1, col. 2. 
commercial establishments; ${ }^{3}$ duties of care derived from state liquor laws; ${ }^{4}$ and principles of common-law negligence. Because courts have applied these three theories only with reluctance, Part III provides a new theory of social-host liability. The proposed theory suggests that courts should find hosts negligent, not for serving an intoxicated guest, but for failing to intervene to prevent the guest from driving while intoxicated. This approach to liability will be shown to be a natural extension of affirmative duties already recognized in tort law.

\section{A Brief Gonsideration of the Underlying Policies}

Policy and proximate-cause considerations underlay the traditional treatment of alcohol-related accidents. Under traditional common-law doctrine, intoxicated individuals were alone responsible for their torts, except where a drinker was so helpless or debauched as to be without willpower. ${ }^{\varnothing}$ Because courts insisted that consumption rather than furnishing was the proximate cause of the injury, blame was focused solely on the drinker, and neither commercial nor private furnishers of alcohol could be held liable. ${ }^{6}$ Even when courts acknowledged the furnisher's role in the chain of causation, liability was still foreclosed on the grounds of foreseeability. Finally, nonliability of furnishers was justified by the argument that questions of extended liability were best left to legislative consideration. ${ }^{7}$

Over the last twenty-five years, however, courts have become more

3 Dramshop acts, also known as civil-damages acts, impose civil liability on furnishers of alcohol for damages done by persons whose intoxication was caused by the furnishers. As of late 1984, nineteen states had dramshop acts. See Silas, Drunk Driver: New Jersey Host Liable, 70 A.B.A. J., Sept. 1984, at 31.

"All states have alcohol-beverage-control acts, also known as "liquor laws"; these criminal laws prohibit the selling or other furnishing of alcohol to high-risk consumers, such as minors or intoxicated persons. See Note, supra note 1, at 447 \& n.12.

- See State ex rel. Joyce v. Hatfield, 197 Md. 249, 252, 78 A.2d 754, 755 (1951) (The common law held liable a defendant who rendered another "helplessly drunk" and then "plac[ed] him bodily, in a state of unconsciousness, in the sleigh and start[ed] the horses."); Halvorson v. Birchfield Boiler, Inc., 76 Wash. 2d 759, 762-63, 458 P.2d 897,899 (1969) (en banc) (A furnisher was liable when a person to whom liquor was sold or given was "in such a state of helplessness or debauchery as to be deprived of his willpower or responsibility for his behavior."); see also Note, Liquor Vendor Liability for Torts of Intoxicated Patrons, 12 BALTIMORE L. REv. 139, 141 n.15 (1982) (At common law, one was not liable for furnishing liquor to an "able-bodied man." An obviously intoxicated individual or a known or habitual drunkard was not an "ablebodied man.").

- See, e.g., Cole v. Rush, 45 Cal. 2d 345, 356, 289 P.2d 450, 457 (1955); see also Note, supra note 5 , at 140 .

7 See Hutchens v. Hankins, 63 N.C. App. 1, 7-8, 303 S.E.2d 584, 588-89 (discussing bases of traditional rule of nonliability), petition denied, 309 N.C. 191, 305 S.E.2d 734 (1983). 
willing to hold bars and restaurants liable for the acts of their intoxicated patrons. ${ }^{8}$ As of 1981 , only fourteen states continued to adhere to the common-law rule insulating commercial furnishers from liability. ${ }^{9}$ Thus, the service of too much alcohol by commercial furnishers is now widely recognized as a proximate cause of injuries caused by intoxicated persons. ${ }^{10}$ Yet most of the jurisdictions that impose liability on vendors of alcohol do not impose it on social hosts. ${ }^{11}$ This discrepancy is puzzling, since the issues regarding the proximate cause of the tort and the damages suffered are the same regardless of whether the furnisher is a vendor or a social host. The fact that courts are resolving vendor and social-host cases differently seems to indicate judicial uncertainty as to the appropriate and acceptable extent of liability. ${ }^{12}$

8 See Note, supra note 5, at 143; cf. Brannigan v. Raybuck, 136 Ariz. 513, 667 P.2d 213 (1983) (justifying judicial imposition of vendor liability by arguing that "[t]his is not judicial legislation, but merely the response of common law to changed social conditions").

- See Nazareno v. Urie, 638 P.2d 671, 674 n.3 (Alaska 1981); see also Note, supra note 5 , at $143 \& \mathrm{n} .35$. The status of the law in Washington is puzzling. As Halligan v. Pupo, 37 Wash. App. 84, 87, 678 P.2d 1295, 1297 (1984), explains, Wilson v. Steinbach, 98 Wash. 2d 434, 438, 656 P.2d 1030, 1032 (1982), accepted the idea of liability for furnishing intoxicants to obviously intoxicated persons without ever directly abandoning the common-law rule. Wilson inaccurately read Halvorson v. Birchfield Boiler, Inc., 76 Wash. 2d 759, 458 P.2d 897 (1969) (en banc), as holding that obviously intoxicated persons fall under the common-law exception to the rule of nonliability for helpless or debauched persons. See Halligan, 37 Wash. App. at 89, 678 P.2d at 1298. However, the Wilson court upheld the trial court's dismissal of the complaint because the plaintiffs failed to establish that the guest's intoxication was obvious to the hosts. See Halligan, 37 Wash App. at 87, 678 P.2d at 1297. The Halligan court followed Wilson's interpretation of Halvorson and imposed liability on a social host, but noted that this conflicted with Hulse v. Driver, 11 Wash. App. 509, 524 P.2d 255 (1974). See Halligan, 37 Wash. App. at 90, 678 P.2d at 1298-99.

10 See, e.g., Ontiveros v. Borak, 136 Ariz. 500, 667 P.2d 200 (1983) (en banc) (imposing vendor liability and noting that "[o]ur common sense tells us that both the furnishing and the drinking are part of the chain of cause and effect that produces accidents . . . "); Alegria v. Payonk, 101 Idaho 617, 619 P.2d 135 (1980); Hutchens v. Hankins, 63 N.C. App. 1, 8, 303 S.E.2d 584, 589 (majority of courts acknowledge proximate cause in vendor liability cases), petition denied, 309 N.C. 191, 305 S.E.2d 734 (1983); Sorenson v. Jarvis, 119 Wis. 2d 627, 648-51, 350 N.W.2d 108, 119-20 (1984) (imposing vendor liability and listing all states that have similarly abrogated the traditional rule).

11 See, e.g., Chastain v. Litton Sys., 694 F.2d 957 (4th Cir. 1982) (liability in North Carolina hinges on defendant's status as a commercial furnisher), cert. denied, 462 U.S. 1106 (1983); Klein v. Raysinger, 504 Pa. 141, 470 A.2d 507, 510 (1983) (collecting cases).

12 Decisions in this area reveal great reluctance to choose a resting place on the "slippery slope" of liability. See, e.g., Alegria v. Payonk, 101 Idaho 617, 623-24, 619 P.2d 135, 141-43 (1980) (Shepard, J., dissenting) (expressing reluctance to impose the same duty on all providers of alcohol-for example, taverns, social hosts, sports facilities, restaurants-and uncertainty as to whether duty would require the server to monitor the drinker's consumption, to urge the drinker not to drive, or to prevent the drinker from committing crimes such as assault); Manning v. Andy, $454 \mathrm{~Pa}$. 237, 240-42, 310 A.2d 75, 77 (1973) (Pomeroy, J., concurring); Sorenson v. Jarvis, 119 Wis. 627, 642- 
Although courts have been reluctant to impose liability on social hosts for the acts of their drunken guests, imposing such liability would be consistent, at least from the victim's perspective, with several underlying goals of the tort system. Probably the most important goal of the tort system is to compensate injured victims. ${ }^{13}$ By extending liability to social hosts, courts would increase the likelihood that all victims of alcohol-related automobile accidents would be adequately compensated. As with vendor liability, social-host liability adds another party's resources to the sources of compensation available to the injured party. Imposing liability on social hosts also eliminates the unfairness of denying compensation to some victims based on the fortuitous circumstance that the person who furnished the drunken driver with alcohol happened to be a social host rather than a vendor. As the California Supreme Court said in a recent case, "[I]t is small comfort to the widow whose husband has been killed in an accident involving an intoxicated driver to learn that the driver received his drinks from a hospitable social host rather than by purchase at a bar."14

A second goal of the tort system fulfilled by social-host liability is the proper attribution of fault for drunken-driving accidents. In recent years, society as a whole has become increasingly aware of the devastating social costs of drunken driving. ${ }^{15}$ One response has been a nationwide trend toward enactment of more stringent drunken-driving legislation, and increasing strictness in enforcing the laws already enacted. ${ }^{16}$

43, 350 N.W.2d 108, 116 (1984).

${ }^{13}$ This factor was considered crucial by the New Jersey Supreme Court in Kelly v. Gwinnell, 96 N.J. 538, 548, 551, 476 A.2d 1219, 1224, 1226 (1984).

14 Coulter v. Superior Court, 21 Cal. 3d 144, 153, 577 P.2d 669, 674, 145 Cal. Rptr. 534, 539 (1978). The particular statute interpreted in Coulter was subsequently amended by the California legislature. See infra notes 59-61 and accompanying text.

${ }^{15}$ Alcohol-related accidents have been estimated to account for " 'as much as onehalf of all highway deaths-or about 25,000 persons annually-and represent an estimated annual economic cost of over $\$ 5$ billion. " Slicer v. Quigley, 180 Conn. 252, 266, 429 A.2d 855, 862 (1980) (Bogdanski, J., dissenting) (quoting CoMPTROLLER General of the United States, The Drinking-Driver Problem-What Can BE DONE ABout IT? 1-2 (1979)). Efforts to redistribute the costs of drunken driving include directing funds collected through drunken-driving fines toward costs incurred in attempts to address the problem. See Rosenbaum, New Bid to Curb Drunken Driving, N.Y. Times, July $1,1984, \S 1$, at 17 , col. 1 .

${ }^{16}$ Legislation aimed at ameliorating the problem of drunken driving has come from both the federal and state levels of government. Galling drunken driving "a grave national problem," President Reagan signed legislation aimed at forcing states to adopt a minimum drinking age of 21 . See N.Y. Times, July 18, 1984, § 1, at 15, col. 1. In response to the problems of alcoholism and drunken driving, Oklahoma, Mississippi, Massachusetts, Florida, and Utah have passed laws either banning or restricting the advertising of alcoholic beverages, and similar bills are pending before other state legislatures. See Hemp, Advertising Bans Versus Free Speech, N.Y. Times, Sept. 9, 1984, § 3 , at 12 , col. 4. State legislatures are being pressured to pass laws providing for imme- 
Where public consensus so clearly deems drunken drivers blameworthy, some of this blame logically should extend to the persons who furnish the means by which these drivers become so dangerous.

Deterrence is a third goal of the tort system likely to be achieved by social-host liability. It seems quite reasonable to believe, as did the New Jersey Supreme Court, that social-host liability will "make it more likely that hosts will take greater care in serving alcoholic beverages at social gatherings so as to avoid . . e economic liability." deed, there are already indications that the New Jersey decision has exerted a deterrent effect since it was handed down last summer. ${ }^{18}$

The case for social-host liability is indeed a strong one, yet, stepping away from the perspective of the victim, one encounters stubborn traditions weighing against the imposition of liability on social hosts. First of all, American traditions of individual responsibility suggest that the primary blame for an alcohol-related accident belongs on the drinker. By tracing the chain of causation back past the drunken driver, however, we see that the host has also contributed to the accident, both by helping to create the drinker's condition and by allowing the drinker to drive. The provider of alcohol may be less blameworthy than the drinker. But how much less? Certainly not enough less to exonerate the provider completely, as did the common law.

If social-host liability is to be imposed, courts should do so in a manner that recognizes our common-sense notion of the lesser degree of responsibility of the host without letting her off the hook completely. A plaintiff thus might be allowed to name the furnisher of alcohol as a

diate confiscation of drivers' licenses upon arrests for drunken driving. See N.Y. Times, July $1,1984, \S 1$, at 17 , col. 1 . Furthermore, states enacting strict drunken-driving laws are eligible for extra federal funds. See Mitchell, Drunken-Driving Bills Afoot, N.Y. Times, Sept. 2, 1984, $\S 11$, at 4, col. 4. Strict enforcement can include the imposition of heavy fines; New Jersey, for example, punishes a first-time offender with a minimum $\$ 250$ fine, a six-month license suspension, and a required payment of $\$ 3,000$ to an enforcement fund. See id.

Other signs of concern include the urgings of the National Transportation Safety Board to state and local officials to set up "sobriety checkpoints" where drivers will be stopped and tested for intoxication, see N.Y. Times, July $1,1984, \S 1$, at 17, col. 1, and the increased enrollments experienced by groups such as Mothers Against Drunk Driving and Students Against Drunk Driving, see N.Y. Times, May 6, 1984, § 11, at 5, col. 1. Such groups have been actively and successfully campaigning against teenage drinking. See N.Y. Times, June 9, 1984, § 1, at 5, col. 3. Efforts to curtail teenage drinking and driving include the establishment of "Safe Rides," a student-run program in high schools throughout the country that provides free rides for students who are unable to drive themselves home or who wish to avoid riding with an intoxicated driver. See Callahan, Teenage Drinking is Target of Groups, N.Y. Times, May 27, $1984, \S 22$, at 1 , col. 1 .

${ }_{17}$ Kelly v. Gwinnell, 96 N.J. 538, 551-52, 476 A.2d 1219, 1226 (1984).

18 See Sullivan, Jersey Hosts Keeping Drunks From Driving, N.Y. Times, Dec.

$30,1984, \S 1$, at 1 , col. 3. 
defendant only if the insurance coverage and other financial resources of the drunken driver are inadequate to compensate the plaintiff for her injuries. In addition, the lesser blameworthiness of the host dictates that we should impose liability on the host, if at all, only for injuries to innocent victims and not for injuries sustained by the drunken driver herself. If the driver is seen as primarily responsible for the accident, it seems obvious that she should not be able to recover against the secondarily responsible host.

A second argument against social-host liability stems from the fact that the type of wrongdoing that generally triggers civil liability is misfeasance rather than nonfeasance. The courts as a rule refuse to punish those who do nothing - who refuse to save people who are drowning, ${ }^{19}$ or who fail to warn a driver that she is about to strike a blind person. ${ }^{20}$ Yet this Comment maintains that the most cogent rationale for imposing liability on social hosts is that they have failed to intervene to prevent their guests from driving while intoxicated-a clear example of liability for nonfeasance. Although most people would accept that the host has a moral duty to intervene, many would question whether we should convert that moral duty into a legal one. Prosser suggests that our jurisprudence is headed in that direction:

This process . . . has been slow, and marked with extreme caution; but there is reason to think that it may continue until it approaches a general holding that the mere knowledge of serious peril, threatening death or great bodily harm to another, which an identified defendant might avoid with little inconvenience, creates a sufficient relation, recognized by every moral and social standard, to impose a duty of action. ${ }^{21}$

Before imposing liability on social hosts, we must be sure that we want to follow this trend and hold people legally responsible for what has traditionally been only a moral obligation.

A third consideration against social-host liability involves the probable social and economic effects of such liability. The "potential revision of cocktail-party customs"22 likely to result from social-host liabil-

19 See Restatement (SECOND) OF TORTS $§ 314$ illustration 4 (1965).

${ }^{20}$ See id. at $\S 314$ illustration 1. But see Huhn v. Dixie Ins. Co., 453 So. $2 d 70$ (Fla. Dist. Ct. App. 1984); Irwin v. Town of Ware, 392 Mass. 745, 467 N.E.2d 1292 (1984). Huhn and Irwin held municipal police liable to persons injured by drunken drivers by virtue of the police's failure to detain, and thus prevent further driving by, drunken drivers whom the police had stopped.

21 W. Prosser, Torts $\S 56$, at 343 (4th ed. 1971) (footnote omitted).

22 Kelly v. Gwinnell, 96 N.J. 538, 555, 476 A.2d 1219, 1227 (1984). 
ity will certainly have a dampening effect on social relationships, because drinking, even to excess, is a firmly-rooted part of American social life. And from an economic perspective, although homeowner's insurance might afford some protection, ${ }^{23}$ the additional cost to every policy holder of obtaining insurance to cover the relatively rare accidents caused by intoxicated guests might outweigh the actual costs of compensating injured victims. ${ }^{24}$ In addition, those not wealthy or foresighted enough to obtain such insurance will risk a considerable loss if they are found liable for injuries caused by a guest's drunken driving. ${ }^{25}$

Finally, even if a court deems it appropriate to hold a host liable, practical difficulties arise in identifying the material facts necessary to prove the case and in obtaining admissible evidence regarding these facts. Who would testify regarding the condition of the guest during the party or on departure? How intoxicated must the guest be or seem before the host is responsible for the guest's actions? Blood alcohol levels rise slowly, and it is possible that a guest's blood alcohol would be higher at the time of an accident than at the time of departure from the host's home. Would proof of blood alcohol levels after an accident be relevant or admissible evidence regarding the guest's state of intoxication on departure from the host's home? These are just a few of the problems that might confront a court or finder of fact considering a social-host case.

As this brief summary shows, there quite clearly is a range of arguments to be made both for and against the imposition of liability on social hosts. Courts addressing the issue today must look to precedent that has traditionally opposed such liability. But perhaps a reevaluation of this tradition is in order. As the underlying issue becomes no less complicated and the costs resulting from drunken driving escalate, social-host liability may gain favor as a viable and desirable way of addressing the problem of alcohol-related automobile accidents. Socialhost liability is clearly appropriate under some circumstances, yet courts have been reluctant to impose liability. The remainder of the Comment examines this reluctance and advances a new theory under which liability can be imposed more logically and consistently than heretofore.

\section{Gonventional Theories of Social-Host Liability}

Courts have used three theories to impose liability on social hosts

\footnotetext{
23 See id. at 551, 476 A.2d at 1225.

24 See id. at 568, 476 A.2d at 1235 (Garibaldi, J., dissenting).

25 See id.
} 
for the acts of their intoxicated guests. Each of these theories has essentially been adopted wholesale from existing judicial and legislative treatments of vendor liability. None of the theories, however, has found strong favor with the courts. This section examines these theories and the problems implicated by their use.

\section{A. The Three Theories}

Judicial extension of dramshop acts ${ }^{26}$ to cover social hosts has probably been the least successful method of imposing liability on noncommercial furnishers, despite the fact that the language in some dramshop acts is broad enough to cover social hosts. ${ }^{27}$ Notwithstanding general reluctance to read dramshop acts to cover noncommercial furnishers, two fairly recent state supreme court decisions extended dramshop laws to persons who were not vendors.

These decisions, Williams v. Klemesrud ${ }^{28}$ in Iowa, and Ross $v$. Ross $^{29}$ in Minnesota, relied on dramshop acts providing anyone injured by an intoxicated person with a right of action against "any person" who by selling or "giving" intoxicating liquor caused the tortfeasor's inebriation..$^{30}$ In each case, plaintiffs were injured by intoxicated minors to whom older friends or relatives had provided liquor. ${ }^{31}$ Both courts declared that the remedial purposes of the dramshop acts mandated a liberal construction embracing actions against noncommercial furnish-

${ }^{28}$ Dramshop acts provide a civil cause of action against furnishers of alcohol for damages resulting from consumers' intoxication. See, e.g., Colo. REv. STAT. § 13-21103 (1973); Conn. Gen. Stat. AnN. § 30-102 (West 1975); Ill. AnN. Stat. ch. 43, $\S 135$ (Smith-Hurd Supp. 1984); MinN. Stat. ANN. $\$ 340.95$ (West Supp. 1984); N.Y. Gen. Oblig. LaW \& 11-101 (McKinney 1978 \& Supp. 1984-85).

${ }_{27}$ See, e.g., Ill. ANN. STat. ch. 43, $\S 135$ (Smith-Hurd Supp. 1984) (providing cause of action for individual injured by intoxicated person against "any person who by selling or giving alcoholic liquor, causes the intoxication of such person"); N.Y. GEN. OBLIG. LAW §11-101 (McKinney 1978 \& Supp. 1984-85) (cause of action for damages from injury by intoxicated person against "any person who shall, by unlawful selling to or unlawfully assisting in procuring liquor for such intoxicated person, have caused or contributed to such intoxication").

28197 N.W.2d 614 (Iowa 1972).

29294 Minn. 115, 200 N.W.2d 149 (1972).

so The dramshop law relied upon in Williams has been repealed; the current statute restricts liability to "any licensee or permittee." IowA CODE ANN. §123.92 (West Supp. 1984). Similarly, Minnesota has deleted the word "giving" from the statute granting a cause of action against the furnisher of alcohol. See Minn. STAT. ANN. § 340.95 (West Supp. 1985). The Minnesota Supreme Court has interpreted this as insulating social hosts from liability based on the statute. See Cady v. Coleman, 315 N.W.2d 593, 595 (Minn. 1982).

31 In Williams, the 20-year-old tortfeasor was supplied with alcohol by a 21 -yearold friend. See 197 N.W.2d at 615. In Ross, the 19-year-old tortfeasor was supplied by his brother and a friend. See 294 Minn. at 116, 200 N.W.2d at 150. 
ers of alcohol. ${ }^{32}$ Thus, although the Iowa legislature had passed a new liquor law restricting civil liability to licensees and permittees, the Williams court adhered to a broad construction of the prior law and imposed liability on the defendant furnisher. ${ }^{33}$ The Ross court similarly concluded that social hosts, as well as vendors, could be responsible for furnishing liquor indiscriminately. ${ }^{34}$

Because of legislative action in Iowa and Minnesota, however, these decisions are now moat. The Iowa legislature had restricted application of its dramshop act to licensees and permittees even before Williams was decided. ${ }^{35}$ And in 1977 the Minnesota legislature deleted the word "giving" from its statute, an action courts have interpreted as signifying disapproval of Ross. ${ }^{36}$

A second and more widely accepted theory of host liability finds a duty of care in alcohol-beverage-control laws, criminal laws that pro-

32 The Williams court declared that a narrow reading of the dramshop act would "impair the remedy and advance the mischief sought to be corrected." 197 N.W.2d at 615. The Ross court similarly concluded that the legislative history of the Minnesota civil-damages act demonstrated an intent to provide a cause of action "against every violator whether in the liquor business or not." 294 Minn. at 119, 200 N.W.2d at 15253.

ss See Williams, 197 N.W.2d at 616. The court noted that "[w]hile the new legislation cannot affect this litigation, it is apparent cases such as this will not arise in the future." Id. But of. Clark v. Mincks, Nos. 83-343, 83-1164 (Iowa Mar. 20, 1985) (finding that social-host liability may be imposed under Iowa's alcohol-beverage-control laws).

34 See Ross, 294 Minn. at 121-22, 200 N.W.2d at 153 ("[N]o reason occurs to us why those who furnish liquor to others, even on social occasions, should not be responsible for protecting innocent third persons from the potential dangers of indiscriminately furnishing such hospitality."). The court's sweeping language is somewhat puzzling, however, given its earlier observation that "[i]f our statute . . . applied to every case for damage resulting from intoxication, whether the furnishing of liquor was legal or illegal, we might well find a different legislative intention . ..." Id. at 121, 200 N.W.2d at 152.

3s See supra notes 30,33 and accompanying text.

s6 See supra note 30 . Recent Minnesota decisions suggest that the reluctance to subject social hosts to liability that followed Ross may have been partly attributable to the theory of liability used in that case. In Holmquist v. Miller, 352 N.W.2d 47 (Minn. Ct. App.), review granted, 360 N.W.2d 1 (Minn. 1984), for example, the court noted that social-host actions based on the state's dramshop act were foreclosed, but went on to allow a cause of action based on negligence principles. See id. at 50-52. The importance of the choice of a theory of liability was foreseen by Justice Rogosheske's special concurrence in the Ross decision. He noted that

no social host worthy of another's visit to his home or to his party should be permitted to ignore his duty to exercise reasonable care for the sobriety of his guest because of the potential harm to innocent third parties which could result if he negligently permits his guest to become intoxicated.

294 Minn. at 124,200 N.W.2d at 154. He went on, however, to question the use of the dramshop act against social hosts because it imposes strict liability. Id. at 124-25, 200 N.W.2d at 154-55. 
hibit the service of alcohol to persons incompetent to handle it. ${ }^{37}$ The approach has been most successful in cases involving intoxicated minors. ${ }^{38}$ Under this analysis, the violation of these laws constitutes negligence per $\mathrm{se}^{30}$ While some alcohol-beverage-control statutes apply only to licensees or permittees ${ }^{40}$ or to situations involving sales ${ }^{41}$ and are thus clearly inapplicable to social hosts, others speak of "any person"42 or of "giving"43 intoxicating beverages to a proscribed class of consumers. The latter types of statutes would seem to lend themselves to providing a basis for social-host liability, and a number of courts have so used them. ${ }^{44}$ Many courts, however, are unwilling to utilize potentially

37 The proscribed classes of consumers typically include minors, habitual drunkards, and intoxicated persons. See, e.g., Colo. Rev. STAT. § 12-47-128(a) (1973) (imposing criminal liability for furnishing liquor to minors, visibly intoxicated persons, or known habitual drunkards); ConN. Gen. Stat. ANN. $§ 30-86$ (West Supp. 1984) (imposing criminal liability for selling or delivering liquor to minors, intoxicated persons, or known habitual drunkards); Ill. ANN. STAT. ch. 43, § 131(a) (Smith-Hurd Supp. 1984) (imposing criminal liability for furnishing liquor to minors, intoxicated persons, or "any person known . . . to be under legal disability or in need of mental treatment"); N.D. CENT. CODE § 5-01-09 (1975) (ruling that delivery of alcohol to a minor, habitual drunkard, incompetent, or intoxicated person constitutes a misdemeanor).

${ }^{38}$ See, e.g., Brockett v. Kitchen Boyd Motor Co., 24 Cal. App. 3d 87, 100 Cal. Rptr. 752 (1972) (a noncommercial furnisher who serves a minor may be liable to anyone injured as a result of the minor's intoxication); Brattain v. Herron, 159 Ind. App. 663, 309 N.E.2d 150 (1974) (violation of alcohol-beverage-control act as it pertains to minors is negligence per se); Congini v. Portersville Valve Co., $504 \mathrm{~Pa}$. 157 , 470 A.2d 515, 518 (1983) (social hosts serving alcohol to a minor were negligent per se under the Pennsylvania Crimes Code but not under the liquor laws); see also Klein v. Raysinger, 504 Pa. 141, 470 A.2d 507, 510 (1983) (citing cases imposing liability on social hosts for serving alcohol to minors). But cf. Manning v. Andy, $454 \mathrm{~Pa} .237,310$ A.2d 75 (1973) (per curiam) (refusing to find civil liability for service to adults under the Pennsylvania Liquor Code); Raysinger, 470 A.2d at 510-11 (following Manning); Douglas v. Schwenk, 479 A.2d 608, 610-11 (Pa. Super. Ct. 1984).

${ }_{3 \theta}$ See, e.g., Brattain v. Herron, 159 Ind. App. 663, 309 N.E.2d 150 (1974).

to See, e.g., Conn. Gen. Stat. Ann. \& 30-86 (West Supp. 1984) (imposition of criminal liability for sale or delivery of alcoholic beverages to a minor, intoxicated person, or habitual drunkard by "any permittee" or "his servant or agent"); ILL. ANN. STAT. ch. 43, § 131 (Smith-Hurd Supp. 1984) (liability imposed on a "licensee" or "any officer, member, representative, agent or employee of such licensee" who sells, gives, or delivers alcohol to minors, intoxicated persons, or persons known to be under legal disability or in need of mental treatment); MASs. ANN. LAws ch. 138, $\$ 69$ (Michie/Law. Co-op. 1981).

${ }^{41}$ See, e.g., N.Y. Alco. Bev. ConT. Law $§ 65$ (McKinney 1970 \& Supp. 198485) (entitled "Prohibited sales and purchases"). (1975).

${ }^{42}$ See, e.g., Colo. Rev. Stat. § 12-47-128 (1973); N.D. Cent. Code § 5-01-09

13 See, e.g., Colo. Rev. Stat. § 12-47-128 (1973); Minn. Stat. AnN. § 340.73 (1972 \& Supp. 1984).

14 See cases cited supra note 38; see also Vesely v. Sager, 5 Cal. 3d 153, 486 P.2d 151, 95 Cal. Rptr. 623 (1971) (en banc) (finding that a presumption of negligence arises from a violation of an alcohol-beverage-control act prohibiting the furnishing of alcohol to an obviously intoxicated person; in this case the drinker was not a minor). 
applicable statutes. Some apply these laws only to commercial furnishers, ${ }^{45}$ and others decline to use them to impose civil liability on anyone. ${ }^{18}$

A third foundation for social-host liability, on which the New Jersey Supreme Court relied in Kelly $v$. Gwinnell, ${ }^{47}$ imposes liability under common-law negligence principles. Under this approach, liability is based on the foreseeability of the guest's drunken driving: "[A] host who serves liquor to an adult social guest, knowing both that the guest is intoxicated and will thereafter be operating a motor vehicle, is liable for injuries inflicted on a third party . . . "48 Prior to Kelly, the two most important cases basing social-host liability on negligence principles were Wiener v. Gamma Phi Chapter of Alpha Tau Omega Fraternity $^{48}$ in Oregon, and Coulter v. Superior Court ${ }^{50}$ in California.

Wiener rejected Oregon's alcohol-beverage-control act as a source of civil liability, b1 but found a duty to refuse to serve a guest "when it would be unreasonable under the circumstances to permit him to drink." ${ }^{2}$ Relying on this theory, the court held that the plaintiff had asserted a cause of action against the fraternity for its service of alcohol to a minor. ${ }^{53}$ The Oregon legislature, however, subsequently curtailed the scope of the Wiener decision by restricting liability to situations in which a guest is "visibly intoxicated" or the server unreasonably fails to ask for identification from a minor or to notice problems with a mi-

The particular statute interpreted in Vesely was subsequently amended by the California legislature. See infra notes 59-61 and accompanying text.

${ }_{45}$ See, e.g., Kohler v. Wray, 114 Misc. 2d 856, 858, 452 N.Y.S.2d 831, 833 (Sup. C. 1982) (refusing to apply New York's alcohol-beverage-control law to hosts in a noncommercial setting, notwithstanding the fact that the hosts had asked guests to help pay for liquor).

16 See, e.g., Runge v. Watts, 180 Mont. 91, 93-94, 589 P.2d 145, 147 (1979); Wiener v. Gamma Phi Chapter of Alpha Tau Omega Fraternity, 258 Or. 632, 638, 485 P.2d 18, 21 (1971); Hulse v. Driver, 11 Wash. App. 509, 513, 524 P.2d 255, 258 (1974).

4796 N.J. 538, 476 A.2d 1219 (1984).

18 Id. at $548,476 \mathrm{~A} .2 \mathrm{~d}$ at 1224.

49 258 Or. 632, 485 P.2d 18 (1971).

so 21 Cal. 3d 144, 577 P.2d 669, 145 Cal. Rptr. 534 (1978). It should be noted that recent Minnesota decisions suggest that social-host liability based on common-law negligence may be adopted in that state. See Walker v. Kennedy, 338 N.W.2d 254 (Minn. 1983) (dictum); Holmquist v. Miller, 352 N.W.2d 47 (Minn. Ct. App.), review granted, 360 N.W.2d 1 (Minn. 1984); cf. supra note 30 (noting that a Minnesota court has rejected the imposition of social-host liability under the state's amended dramshop act).

s1 See 258 Or. at 638,485 P.2d at 21.

s2 Id.

ss See id. at 643, 458 P.2d at 23.

s4 OR. REv. STAT. § 30.955 (1981); see also Note, supra note 1, at 472 \& n.266. 
nor's identification. .5

The Coulter case was the last in a line of California cases progressively extending liability for the acts of drunken drivers. ${ }^{56}$ In Coulter, the California Supreme Court recognized both a statutory and a common-law basis for imposing liability on noncommercial suppliers of alcohol. $^{57}$ The court set forth its common-law theory in terms of foreseeability: "We think it evident that the service of alcoholic beverages to an obviously intoxicated person who intends to drive a motor vehicle creates a reasonably foreseeable risk of injury to those on the highway. ... Simply put, one who serves alcoholic beverages under such circumstances fails to use reasonable care."

Like the Wiener decision, Coulter prompted a negative legislative reaction. The California legislature amended its alcohol-beverage-control laws and civil code to forbid imposing liability on any server of alcohol, commercial or otherwise, ${ }^{50}$ except when a licensee furnishes liquor to an obviously intoxicated minor. ${ }^{60}$ At least one California court has since applied these amended laws to insulate social hosts from responsibility for their guests' actions. ${ }^{\mathbf{6 1}}$ Thus, the New Jersey Supreme Court's decision in Kelly is now the leading case basing social-host liability purely on common-law negligence principles.

\section{B. Problems With the Conventional Theories of Liability}

Courts have rationalized their rejection of social-host liability in a number of ways. Some have clung to the common-law tradition, stating that legislative failure to pass a dramshop act manifests popular sentiment against imposing civil liability on furnishers of alcohol. ${ }^{62}$ Other n.266.

ss See Or. Rev. STAT. $§ 30.960$ (1981); see also Note, supra note 1, at 472 \&

${ }^{58}$ Cases preceding Coulter were Vesely v. Sager, 5 Cal. 3d 153, 486 P.2d 151, 95 Cal. Rptr. 623 (1971) (en banc) (overruling the common-law rule of nonliability for commercial furnishers and finding that a presumption of negligence arises from a violation of the state's alcohol-beverage-control act); Brockett v. Kitchen Boyd Motor Co., 24 Cal. App. 3d 87, 100 Cal. Rptr. 752 (1972) (Vesely's logic leads to the conclusion that a social host who knowingly serves a minor should be liable); Bernhard v. Harrah's Club, 16 Cal. 3d 313, 546 P.2d 719, 128 Cal. Rptr. 215 (en banc) (finding that "there was no bar to civil liability under modern negligence law"), cert. denied, 429 U.S. 859 (1976).

${ }^{57}$ See 21 Cal. 3d at 152, 577 P.2d at 673, 145 Cal. Rptr. at 538.

${ }^{38}$ Id. at 152-53, 577 P.2d at 674, $145 \mathrm{Cal}$. Rptr. at 539 (footnote omitted).

so See Clendening v. Shipton, 149 Cal. App. 3d 191, 196 Cal. Rptr. 654, 657 (1983); see also Note, supra note 1 , at 464-65 \& n.183.

${ }^{60}$ See CaI. Bus. \& Prof. Code $\S \S 25602$ (b)-(c), 25602.1 (West Supp. 1984).

61 See Strang v. Cabrol, No. S.F. 24,762 (Cal. Dec. 27, 1984) (the sole exception to a server's immunity from liability arises when a licensee furnishes liquor to an obviously intoxicated minor).

${ }_{62}$ See, e.g., Felder v. Butler, 292 Md. 174, 184, 438 A.2d 494, 499 (1981); State 
courts have declared that no cause of action is available except under the provisions of the state's dramshop act. In some of these cases the dramshop acts, by their terms, do not reach social hosts; in others courts have interpreted the laws as not reaching so far. ${ }^{63}$ Still other courts have ruled that alcohol-beverage-control statutes making it a crime to serve minors or intoxicated persons do not necessarily impose a standard of care or justify a finding of negligence per se. ${ }^{64}$

Judicial reluctance to impose liability under any of the three conventional theories is not entirely unjustified. Often alcohol-beveragecontrol statutes or dramshop acts simply cannot be stretched to cover social hosts. ${ }^{65}$ Even where a court might interpret a statute so as to reach a social host, the statute may by its own terms be so restricted as to be undesirable as a basis for liability ${ }^{6 B}$ Courts may also be hesitant to impose social-host liability in the face of likely legislative reversal. ${ }^{67}$ Most importantly, the strict liability imposed by dramshop acts and some alcohol-beverage-control statutes may be unduly harsh in socialhost situations because hosts may be less capable than vendors of controlling consumers' intake and spreading the costs of damages. ${ }^{68}$

The conventional theories also have several practical deficiencies. First, because each of the conventional theories focuses on the actual

ex rel. Joyce v. Hatfield, 197 Md. 249, 255-56, 78 A.2d 754, 757 (1951); Runge v. Watts, 180 Mont. 91, 94, 589 P.2d 145, 147 (1979).

63 See, e.g., Miller v. Owens-Illinois Glass Co., 48 Ill. App. 2d 412, 199 N.E.2d 300 (1964) (dramshop act providing cause of action against "any person . . . giving alcoholic liquor" is applicable only to those selling liquor); Cady v. Coleman, 315 N.W.2d 593, 595 (Minn. 1982) (legislature's deletion of the words "or giving" from dramshop act insulates social hosts from liability); Edgar v. Kajet, 84 Misc. 2d 100, 103-04, 375 N.Y.S.2d 548, 550-52 (Sup. Ct. 1975) (New York dramshop act applies only to commercial furnishers), aff d, 55 A.D.2d 597, 389 N.Y.S.2d 631 (1976); Paul v. Hogan, 56 A.D.2d 723, 392 N.Y.S.2d 766 (1979) (granting motion to dismiss dramshop claim where plaintiff failed to allege a sale).

64 See cases cited supra note 46.

os See, e.g., Conn. Gen. STat. Ann. § 30-86 (West Supp. 1984) (imposing criminal liability for sale or delivery of alcoholic beverages to a minor, intoxicated person, or habitual drunkard by "any permittee" or "his servant or agent"); ILL. ANN. STar. ch. 43, §131 (Smith-Hurd Supp. 1984) (dramshop act imposing liability on a "licensee" who sells, gives, or delivers alcohol to minors, intoxicated persons, or persons known to be under a legal disability or in need of mental treatment); MAss. ANN. LAws ch. 138, \& 69 (Michie/Law. Co-op. 1981) (alcohol-beverage-control law referring to alcoholic beverages "sold or delivered on any premises licensed under this chapter"); MINN. Stat. ANN. $§ 340.95$ (West Supp. 1985) (dramshop liability applies only to "illegally selling or bartering" alcohol).

so See, e.g., Colo. REv. STat. § 13-21-103 (1974) (imposing no liability against furnishers unless family members or an employer provide written or printed notice not to serve the drunkard); Ill. ANN. STaT. ch. 43, § 135 (Smith-Hurd 1984) (restricting recovery to $\$ 15,000$ ).

67 See supra text accompanying notes 35-36 \& 59-61.

os See Note, supra note 1 , at 458. 
service of alcohol as the negligent act, the theories require that hosts closely and constantly monitor the sobriety of guests who plan to drive. Such surveillance is likely to be difficult and to put a strain on social relationships. Second, because basing negligence on violation of liquor laws has been successful almost exclusively in cases involving minors, the theory has failed to embrace a large number of cases it could be covering. Finally, dramshop laws and alcohol-beverage-control acts tend to address situations in which a furnisher serves an already intoxicated individual, and not situations in which a sober individual becomes drunk as a result of being served liquor by the host. ${ }^{69}$ It makes little sense to say that a host should be liable for serving an already intoxicated guest but not for rendering a guest drunk in the first place; in either case, the guest will be a dangerous driver. As Justice Mosk of the California Supreme Court noted, "The prohibition is against providing alcoholic beverages to one who is already intoxicated. The law frowns upon adding a straw to a camel's back previously broken."

\section{The Duty to Intervene to Prevent Drunken Driving: \\ A New Theory of Social-Host Liability}

This section sets forth a new theory for social-host cases that bases liability not on the host's act of providing alcohol but on her failure to act to prevent guests from driving while drunk. In practical terms, this theory demands that a host evaluate the condition of a guest preparing to drive home. If the host finds the guest to be in no condition to drive, the host would be under a legal obligation to intervene to deter the guest from driving.

This proposed theory for social-host liability is sensitive to a number of the concerns discussed above. First, by placing the locus of negligence at the guest's departure, the new theory requires hosts to evaluate the sobriety of their guests only once. Further, this theory imposes liability both when hosts serve already intoxicated guests and when hosts render guests drunk in the first place. Grounded in negligence principles, the theory is also more generally applicable than conventional theories because it operates independently of the existence or applicability of dramshop acts or alcohol-beverage-control laws. Finally, the theory avoids direct confrontation with the traditional rule of nonliability by

${ }^{6 \theta}$ Some dramshop acts, however, expressly cover instances in which the furnisher "caused" the consumer's intoxication. See, e.g., ILL. ANN. STat. ch. 43, $§ 135$ (SmithHurd 1984).

${ }^{20}$ Coulter, 21 Cal. 3d at 156, 577 P.2d at 676, 145 Cal. Rptr. at 541 (Mosk, J., concurring). 
seeking its foundation in the common-law duty to act affirmatively to prevent harm.

\section{A. Sources of a Duty-to-Intervene Theory}

Extending either of two common-law tort principles can provide the basis for this theory of social-host liability. The first principle is that an individual must take steps to control another and to prevent the other from causing physical harm where "a special relation exists between the actor and the third person which imposes a duty upon the actor to control the third person's conduct."'71 The second provides that, once an individual realizes or should realize that her actions have created an unreasonable risk of causing physical harm to another, she must "exercise reasonable care to prevent the risk from taking effect."?2 Although courts have not applied these principles in social-host cases, they have applied them in a number of analogous situations. The conceptual step from imposing affirmative duties in these other contexts to imposing such duties in social-host cases is both small and appropriate.

1. Controlling the Conduct of Another: The "Special Relationship" Requirement

The primary issue in applying the duty to control another is whether there is a "special relationship" between the actor and the person the actor is to control. In attempting to characterize special relationships, many courts have generalized and have thereby oversimplified the inquiry. For example, some courts have defined the duty by reference either to a relationship conferring a right to control ${ }^{73}$ or to a relationship of "dependence or mutual dependence."74 Such definitions, however, are not helpful in predicting when most courts will find a relationship implicating a duty to control.

Courts have recognized a duty to control in three types of special relationships analogous to the social-host relationship: relationships be-

71 Restatement (SECOND) OF TORTS § 315 (1965).

${ }^{22}$ Id. $\S 321$ (1965). This duty is classified under the title "Duty to Aid Others," while the duty imposed by section 315 is under the title "Duty to Control the Conduct of Third Persons." In many situations, however, including those involving drunken driving, the question whether the required act is to control the injurer or to protect the injured is essentially moot.

73 See Sports, Inc. v. Gilbert, 431 N.E.2d 534, 538 (Ind. Ct. App. 1982) ("We know of no case from any jurisdiction which imposes a duty to control a third person when no right to control exists."). (1980).

${ }^{74}$ Buford v. State, 104 Cal. App. 3d 811, 821, 823, 164 Cal. Rptr. 264, 270, 271 
tween an individual in charge of a person with dangerous propensities and the dangerous person, ${ }^{75}$ between a master and servant, ${ }^{78}$ and between a landowner and a person using the owner's land or chattel in her presence. ${ }^{77}$

\section{a. Duties Regarding Dangerous Persons}

Of the three special relationships noted above, the duty to control a dangerous person is the most controversial and elusive. Most courts agree, however, that absent governmental immunity, ${ }^{78}$ private and public persons or entities having custody of dangerous persons have a duty to control and restrain those persons so that they do not harm others. This duty clearly applies to prisons, ${ }^{79}$ juvenile detention centers, ${ }^{80}$ and insane asylums or other psychiatric facilities. ${ }^{81}$

This duty is certainly not an onerous one; in general it requires these persons and institutions to do upon pain of civil liability only what their jobs or functions already require of them. At least one court, however, has suggested that the scope of the duty to control is "commensurate with the risk"82 of failure to control. Under such a standard, the extent of the duty may well exceed the normal requirements of the custodian's job. In addition, at least one court has extended the duty to restrain dangerous persons or to warn others of their violent propensities to a case where the custodian's terms of employment merely required supervision, rather than incarceration, of the charge. ${ }^{83}$

The leading case applying the duty to control dangerous persons,

78 See Restatement (SECOND) of ToRTs § 319 (1965).

${ }^{76}$ See id. § 317.

77 See id. $\$ 318$.

${ }^{78}$ Questions of governmental immunity arise frequently in cases concerning staterun asylums or prisons. See, e.g., Buford v. State, 104 Cal. App. 3d 811, 825-30, 164 Cal. Rptr. 264, 272-75 (1980). Such issues are not applicable to social-host situations.

${ }_{79}$ See, e.g., Cansler v. State, 234 Kan. 554, 564, 675 P.2d 57, 66 (1984).

Bo See, e.g., Christensen v. Epley, 36 Or. App. 535, 541, 585 P.2d 416, 421 (1978), affd, 287 Or. 539, 601 P.2d 1216 (1979).

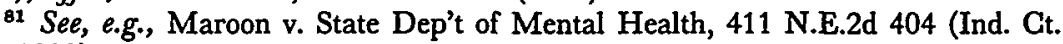
App. 1980).

82 Cansler v. State, 234 Kan. 554, 565, 675 P.2d 57, 66 (1984) (holding that the state had a duty to notify area residents and law enforcement officials of a major prison break).

${ }^{83}$ In Johnson v. State, 69 Cal. 2d 782, 447 P.2d 352, 73 Cal. Rptr. 240 (1968) (en banc), the Galifornia Supreme Court held that the state's youth authority had a duty to warn a foster mother of "latent, dangerous qualities suggested by the [parolee youth's] history or character." Id. at 785, 447 P.2d at 355, 73 Cal. Rptr. at 243. Although the logic of the decision is more closely analogous to section 321 analysis, the facts and holding bear a strong resemblance to the section 315 cases here under discussion. 
Tarasoff $v$. Regents of the University of California, ${ }^{84}$ involves one of the duty's broadest extensions. In Tarasoff, the California Supreme Court imposed the duty on therapists at an outpatient psychiatric clinic. ${ }^{85}$ According to the plaintiffs' allegations, a patient at the clinic told one of the psychologists that he intended to kill Tatiana Tarasoff. At the psychologist's request, campus police took the patient into custody but, "satisfied that [he] was rational, released him on his promise to stay away from Tatiana." the patient's release, they took no steps to warn Tatiana, or anyone else, of the threat. A short time later, the patient killed Tatiana. ${ }^{87}$

In an opinion by Justice Tobriner, the court concluded that the psychotherapist-patient relationship in the case satisfied the special-relationship requirement necessary to impose a duty to control or warn of potentially dangerous behavior ${ }^{88}$ The court characterized the duty arising from the relationship as "a duty to exercise reasonable care to protect the foreseeable victims of the danger." 89 The court went on to state that "the adequacy of the therapist's conduct must be measured against the traditional negligence standard . . . of reasonable care under the circumstances." 90

Tarasoff's breadth, unmatched by most similar cases, has two aspects. The first is that the court found the special-relationship test satisfied in a situation different from those previously recognized. The relationship between a voluntary outpatient and a therapist is nonrestraining and noncoercive, and it continues only as long as the two parties wish. Thus, the therapist possesses little ability or right to control the patient. The second aspect of the decision's breadth is that the duty imposed is one of "reasonable care under the circumstances." Thus, in contrast to other cases defining the duties of psychiatrists and psychiatric facilities, ${ }^{92}$ Tarasoff does not state that a warning is suffi-

84 17 Cal. 3d 425, 551 P.2d 334, 131 Cal. Rptr. 14 (1976).

${ }^{\text {ss }}$ See id. at 431, 551 P.2d at 340, 131 Cal. Rptr. at 20.

${ }^{88}$ Id. at 432,551 P.2d at 341,131 Cal. Rptr. at 21.

87 See id. at 433, 551 P.2d at 341, 131 Cal. Rptr. at 21.

88 See id. at 435, 551 P.2d at 342-43, 131 Cal. Rptr. at 22-23.

${ }^{80}$ Id. at 439,551 P.2d at 345, 131 Cal. Rptr. at 25.

90 Id. (emphasis added).

91 Id.

${ }^{22}$ See, e.g., Brady v. Hopper, 570 F. Supp. 1333, 1339 (D. Colo. 1983) (adopting a "specific threats to specific victims" rule); Leedy v. Hartnett, 510 F. Supp. 1125, 1130 (M.D. Pa. 1981), affd, 676 F.2d 686 (3d Cir. 1982) (finding no duty where the patient had not made any threats against the victims and there was no evidence that he posed any greater danger to them than to the public at large); Buford v. State, $104 \mathrm{Cal}$. App. 3d 811, 824, 164 Cal. Rptr. 264, 272 (1980) (finding a duty to warn foreseeable victims about the release of a dangerous mental patient); Davis v. Lhim, 124 Mich. App. 291, 303, 335 N.W.2d 481, 488-89 (1983) (psychiatrist who released a patient 
cient, nor does it imply that a specific, identifiable victim must exist before any duty to warn is required. ${ }^{83}$

A general statement of the Tarasoff rule, then, might be that one who has developed a relationship with another person, and has come to know of the other's dangerous propensities, has a duty to take reasonable care to protect potential victims of the dangerous person. The fact patterns of social-host cases fit easily into this general rule. Indeed, the relationship between a host and an intoxicated guest appears to be the more appropriate source of liability, because the host has to some extent created the dangerous condition, while a psychotherapist merely discovers it.

Cases decided since Tarasoff, however, generally do not accept the decision in its entirety. ${ }^{94}$ Although Tarasoff has been used in other factual situations, ${ }^{95}$ many courts have imposed only a duty to warn rather than a duty to use reasonable care. Even then, the duty may be restricted to specific "foreseeable" or "readily identifiable" victims. ${ }^{96}$ An-

from a psychiatric hospital owed a duty to warn only those persons readily identifiable as foreseeably endangered); McIntosh v. Milano, 168 N.J. Super. 466; 489, 403 A.2d 500, 511-12 (Law Div. 1979) (finding a duty to protect persons whom psychiatrist determines or should determine to be in danger from the patient). But see Lipari v. Sears, Roebuck \& Co., 497 F. Supp. 185, 193-95 (D. Neb. 1980) (finding that liability extends to all persons foreseeably endangered, even those unknown to the psychiatric facility; also holding that warnings might not always be sufficient); Petersen v. State, 100 Wash. $2 \mathrm{~d} \mathrm{421}, 428,671$ P.2d 230, 237 (1983) (en banc) (finding a duty to protect "anyone who might foreseeably be endangered" by a mental patient).

${ }^{93}$ See supra text accompanying note 90 . Although the case did involve a readily identifiable victim, "the Tarasoff decision did not emphasize the identifiability of the victim." Petersen v. State, 100 Wash. 2d 421, 427-28, 671 P.2d 230, 237 (1983) (en banc). Moreover, the phrase "foreseeable victim" does not necessarily imply, nor did Justice Tobriner apparently mean it to imply, see infra note 96 (quoting from a subsequent opinion by Justice Tobriner), a specifically identified or identifiable person.

* See cases cited supra note 92; see also Bradley Center, Inc. v. Wessner, 161 Ga. App. 576, 581, 287 S.E.2d 716, 721 (finding an independent duty on the part of a hospital to control a psychiatric patient when the treatment involves an exercise of control over the patient's freedom of movement), affd, $250 \mathrm{Ga}$. 199, 296 S.E.2d 693 (1982).

${ }_{\text {9s }}$ See, e.g., Buford v. State, 104 Cal. App. 3d 811, 817, 164 Cal. Rptr. 264, 266 (1980) (patient released from state mental hospital and later placed on "unauthorized leave of absence" status); Davis v. Lhim, 124 Mich. App. 291, 335 N.W.2d 481 (1983) (patient released from psychiatric hospital).

${ }^{26}$ See supra note 92. Tarasoff's scope has also been narrowed in California. In Thompson v. County of Alameda, 27 Cal. 3d 741, 614 P.2d 728, 167 Cal. Rptr. 70 (1980) (en banc), the defendant County temporarily released a juvenile delinquent with known violent propensities into his mother's custody. Prior to his release the youth had threatened to kill a young child in his neighborhood, but the threat was not divulged to the child's mother, the police, or any of the area residents. Shortly after his release, the youth killed the plaintiffs' son. See id. at 746, 614 P.2d at 730, 167 Cal. Rptr. at 72. Despite the case's obvious similarity to Tarasoff, the court found that the county had no general duty to warn of the danger. The court held that the duty to warn exists when "the released offender poses a predictable threat of harm to a named or readily 
other California case, Harland $v$. State, ${ }^{97}$ is somewhat closer to the social-host situation. Harland involved a resident of a state veterans' home who was being regularly treated with a variety of central-nervous-system depressants. Driving while on medication during a temporary leave from the home, the patient was involved in a collision. ${ }^{98}$ The plaintiffs advanced a special-relationship theory in order to impose liability on the state, but the court held that "the risk was not one that could be guarded against by warning potential victims" and that measures to prevent the veteran from driving his car would be "paternalistic" and unlawful. ${ }^{90}$ Thus, despite evidence of a special relationship and an ability to control a potentially dangerous person, the state was held to have no duty to prevent the person from driving.

The outcome of Harland, considering its similarity to social-host cases, appears damaging to a duty-to-intervene theory of host liability. The damage may be somewhat mitigated, however, by the fact that the physicians for the veterans' home had warned the veteran against driving while on medication. ${ }^{100}$ It could be contended that such warnings fulfilled the doctors' duties under negligence principles. In fact, some courts have held that such a warning is required of physicians prescribing intoxicating drugs ${ }^{101}$ or drugs causing drowsiness or lassitude. ${ }^{102}$ An Iowa court suggested imposing a similar duty on a physician treating a patient suffering from seizures. ${ }^{103}$

This duty to warn a person not to drive because of her medical condition is certainly relevant to social-host situations. Like the physician in the drug cases, a social host provides a substance that may render a driver dangerous. The host also resembles the physician in the seizure case by virtue of her knowledge that the guest is a potentially

identifiable victim or group of victims who can be effectively warned of the danger." Id. at 758,614 P.2d at 738, 167 Cal. Rptr. at 80 .

Justice Tobriner, the author of Tarasoff, dissented vigorously. He argued that "[t]he County, having custody of James [the juvenile delinquent], stood in a 'special relationship' to James that imports a duty to control his conduct and to warn of danger. ... [T]he absence of an identifiable victim does not postulate the absence of a duty of reasonable care." Id. at 759-60, 614 P.2d at 738-39, 167 Cal. Rptr. at 80-81 (Tobriner, J., dissenting).

ดว 75 Cal. App. 3d 475, 142 Cal. Rptr. 201 (1977).

${ }^{98}$ See id. at 481-82, 142 Cal Rptr. at 205.

${ }^{99}$ See id. at 482, 142 Cal. Rptr. at 205.

100 See id.

101 See, e.g., Gooden v. Tips, 651 S.W.2d 364, 370 (Tex. Giv. App. 1983).

102 See, e.g., Kaiser v. Suburban Transp. Sys., 65 Wash. 2d 461, 464, 398 P.2d 14, 16, corrected, 401 P.2d 350 (1965).

103 Freese v. Lemmon, 210 N.W.2d 576, 579 (Iowa 1973) (cause of action is made out by allegations that physician negligently failed to advise patient not to drive, negligently failed to warn patient of dangers involved in driving, and negligently advised patient that he could drive). 
dangerous driver. The argument for imposing this duty is actually stronger in social-host cases than in physician cases because the host knows that the driver is currently dangerous; the physician is only projecting that the patient may be dangerous at some time in the future. ${ }^{104}$

\section{b. The Duty of an Employer to Control Employees}

According to section 317 of the Restatement (Second) of Torts, ${ }^{105}$ there are only a few situations in which an employer has a duty to control an employee acting outside the scope of employment. ${ }^{106}$ In general, this duty is imposed only when the employee is using the employer's chattel or is on the employer's premises and the employer knows, or has reason to know, of the necessity and opportunity to exercise control. ${ }^{107}$ In this respect, it is noteworthy that even an absent employer may risk liability for the actions of her employees. ${ }^{108}$

In several cases closely analogous to the social-host context, employers have been held liable for injuries caused by their employees' drunken driving after office parties. In Brockett $v$. Kitchen Boyd Motor Co., ${ }^{109}$ the defendant employer served a large amount of alcohol to his minor employee, put the employee in a car, and directed him to drive home. The employee subsequently was involved in an auto accident in which the plaintiffs were injured. ${ }^{110}$ Although the court made much of the fact that the employer "procured" the intoxication of the minor, placed him in a car, and then directed him to drive, ${ }^{111}$ its holding was broad enough to reach normal social-host situations. The court found that the employer "had assumed the responsibility for the well-being and proper conduct of the minor" both for the benefit of the minor and for the protection of the general public. ${ }^{112}$ The court thus held that, "in accordance with the mores of the general public, Kitchen Boyd Motor Company should be held responsible for what resulted."113

Recent decisions in other states confirm the general applicability of

104 It is important to differentiate the duty to warn at issue here, which requires warning the dangerous person herself, from the Tarasoff duty to warn the potential victims.

105 Restatement (Second) of Torts $§ 317$ (1965).

${ }_{100}$ See id. If the employee is acting within the scope of her employment, then the employer may be held liable under the doctrine of respondeat superior.

107 See id.

108 See id.

109264 Cal. App. 2d 69, 70 Cal. Rptr. 136 (1968).

11 See id. at 70, 70 Cal. Rptr. at 137.

11 See id. at 72-73, 70 Cal. Rptr. at 139.

112 Id. at 72,70 Cal. Rptr. at 138.

113 Id. at $73,70 \mathrm{Cal}$. Rptr. at 139. It is important to note that Brockett never refers to section 315 or section 317 of the Restatement in its analysis. 
the principles set forth in Brockett. ${ }^{114}$ In Meany v. Newell, ${ }^{116}$ for example, an adult employee of the defendant became drunk at the defendant's office Christmas party. The employer was aware that when the employee left the party he was dangerously intoxicated. ${ }^{116}$ The court noted that the employee "was consuming intoxicating beverages on Cardinal's [the employer's] premises during working hours when Cardinal had the ability to control him, and Cardinal knew of the necessity and opportunity to keep him from driving." 117 Referring to earlier Minnesota cases indicating that "some special relationships can support a negligence action against a provider of intoxicating beverages, ${ }^{\text {"118 }}$ the court found that the facts of the case "fit within section 317." thermore, although the accident occurred off the employer's property, the court ruled that this fact did not determine the issue of liability. The determination hinged instead upon a jury finding as to the continuity of the chain of causation. ${ }^{120}$

The Meany court attempted to distinguish social-host situations, ${ }^{121}$ but the facts of the case are actually quite similar to the social-host

114 See Meany v. Newell, 352 N.W.2d 779 (Minn. Ct. App.) (employer may be held liable for injuries caused by employee who became intoxicated at an office party), review granted, 359 N.W.2d 571 (Minn. 1984); Otis Eng'g Corp. v. Clark, 668 S.W.2d 307 (Tex. 1983) (employer who sent intoxicated employee home may be held liable for injuries caused by employee's drunken driving); Robertson v. LeMaster, 301 S.E.2d 563 (W. Va. 1983) (employer may be held liable for injuries resulting from an accident caused by an employee forced to work for 27 hours); see also Davis v. Sam Goody, Inc., 195 N.J. Super. 423, 480 A.2d 212 (App. Div. 1984) (liability of "commercial host" to be evaluated under "conventional negligence analysis"); Walker v. Key, 101 N.M. 631, 686 P.2d 973 (Ct. App.) (complaint alleging unlawful furnishing of liquor to minor by employer, in a social context, states a valid cause of action), cert. quashed, 101 N.M. 555, 685 P.2d 963 (1984); MRC Properties, Inc. v. Gries, 98 N.M. 710, 652 P.2d 732 (1982) (employer can be held liable for injuries to third party caused by acts of minor employee to whom employer had provided liquor).

118352 N.W.2d 779 (Minn. Ct. App.), review granted, 359 N.W.2d 571 (Minn. 1984).

116 See id.

${ }^{117}$ Id. at 782 (emphasis added). Like other decisions, Meany primarily focuses on the provision of alcohol to the employee; however, this language stresses the employer's negligence in allowing the employee to drive. Otis Eng'g Corp. v. Clark, 668 S.W.2d 307 (Tex. 1983), and Robertson v. LeMaster, 301 S.E.2d 563 (W. Va. 1983), similarly stress the employer's negligence in allowing the employee to drive.

118 Meany, 352 N.W.2d at 781.

119 Id. at 782.

120 See id. An Indiana appeals court faced with a similar problem interpreted section 317 of the Restatement rigidly and found the employer not liable. See Pursley v. Ford Motor Co., 462 N.E.2d 247 (Ind. Ct. App. 1984).

${ }^{121}$ The court emphasized the employer's position of authority, presumably implying that such authority enhanced the defendant's ability to control the drinker and justified the imposition of a higher standard of care. See Meany, 352 N.W.2d at 782 (stating that "an employer's position of authority over employees sufficiently distinguishes it from the normal social-host situation and accordingly calls for increased responsibility"). 
scenario. Although the employer/employee relationship is clearly different from a typical host/guest relationship, in the context of a Christmas party the line between work and social life begins to blur, and questions arise. Would the employer be liable for the employee's acts if the party were a purely social function hosted by the employer, rather than a company Christmas party? ${ }^{122}$ Can the duty be imposed only where the function is both work-related and on premises controlled by the employer? Given that the Restatement characterizes the duties of employers and hosts in essentially identical terms, ${ }^{123}$ and that Meany permits the chain of causation to extend to off-premises accidents caused by the employee, it is not unreasonable to think that the same liability should arise in social-host cases.

\section{c. The Duty of a Landowner to Control Persons on Her Property}

The common law duty of a landowner to control persons using the owner's land or chattels in her presence has generally been applied to protect others on the property only when the landowner has the ability to exercise control and knows of the necessity for doing so. ${ }^{124}$ This duty has been extended to situations involving injuries inflicted upon persons outside the defendant's premises due to the behavior of guests on the premises. ${ }^{125}$ But apparently no such duty has been imposed in cases involving injuries caused by a guest while off the premises, except when the guest was using chattels belonging to the host. Thus, New York courts have stated that a host's duty to control drunken guests extends "only to those persons who are physically present" on the premises ${ }^{128}$ or who are in an area in which "supervision and control reasonably may be exercised" by the host. ${ }^{127}$

122 This hypothetical question closely resembles the facts of Walker v. Key, 101 N.M. 631, 686 P.2d 973 (Ct. App.), cert. quashed, 101 N.M. 555, 685 P.2d 963 (1984). In that case, the hosts were the employers of the minor guest, but the corporate defendant denied that it sponsored the party.

${ }^{123}$ See RESTATEMENT (SECOND) OF TORTs $\$ \S 317-18$ (1965).

124 See id. \& 318. See also Bartkowiak v. Saint Adalbert's Roman Catholic Church Soc'y, 40 A.D.2d 306, 310, 340 N.Y.S.2d 137, 142 (App. Div. 1973). In Bartkowiak, a church hosting a lawn fete was held liable for the death of a guest killed by another guest who was intoxicated; the assailant was boisterous and aggressive before the attack, and the court held that the church could have used the security guards present to control him. See id. at 309, 340 N.Y.S.2d at 142. But see Kohler v. Wray, 114 Misc. 2d 856, 861, 452 N.Y.S.2d 831, 835 (Sup. Ct. 1982) (host not liable after plaintiff failed to prove that host knew or should have known of the danger posed by one of the guests).

125 See Connolly v. Nicollet Hotel, 254 Minn. 373, 95 N.W.2d 657 (1959).

126 See Paul v. Hogan, 56 A.D.2d 723, 724, 392 N.Y.S.2d 766, 768 (App. Div. 1977) (memorandum opinion).

${ }_{127}$ See Schirmer v. Yost, 60 A.D.2d 789, 789, 400 N.Y.S.2d 655, 656 (App. Div. 
The artificiality of this distinction becomes apparent when real-life situations are considered. A host cannot control or supervise a guest's driving at points distant from the host's home, but she can and should exercise such control when a guest prepares to leave or begins to drive, because these actions occur on the premises. As was seen in the cases involving employer/employee relationships, courts have recognized the sensibility of this type of argument.

\section{The Duty to Act When Prior Conduct Is Found to Be Dangerous}

Section 321 of the Restatement (Second) of Torts embodies the common-law notion that one who creates a dangerous situation or sets a destructive force into motion must take reasonable steps to intervene once she recognizes, or should recognize, the danger. ${ }^{128}$ This duty may appear quite different from the section 315 duty to control the conduct of another; ${ }^{.29}$ however, an examination of cases utilizing section 321 demonstrates its potential for use in the social-host context.

Early cases applied the doctrine in section 321 to persons who created an obstruction in the roadway and imposed a duty to remove the obstruction or to warn of the danger. ${ }^{130}$ More recently, a Wisconsin court used section 321 to hold that a farmer whose trucks had tracked mud onto the road near his property had a duty, once he became aware of the danger, to use reasonable care to ensure that the mud would not cause traffic accidents. ${ }^{131}$ Other courts have relied on section 321 in imposing a duty to intervene in more complex situations. ${ }^{\mathbf{1 3 2}}$

1977) (memorandum opinion).

${ }_{128}$ See Restatement (SECOND) OF TORTS § 321 (1965).

129 See id. § 315.

130 See, e.g., Simonsen v. Thorin, 120 Neb. 684, 234 N.W. 628 (1931). For an early discussion of the doctrine in road obstruction cases and other contexts, see 20 Tex. L. Rev. 772 (1941-42).

131 See Schicker v. Leick, 40 Wis. 2d 295, 162 N.W.2d 66 (1968). Schicker explicitly utilized section 321 , but also distinguished earlier cases, noting that they went "too far as applied to the facts of this case." See id. at 303,162 N.W.2d at 71. The farmer was not required to maintain his property to prevent dragging mud onto the highway; rather, he was required to correct the danger once he discovered it.

${ }_{132}$ See, e.g., United States v. Furumizo, 381 F.2d 965 (9th Cir. 1967); Bangor \& A.R.R. v. The Ship Fernview, 455 F. Supp. 1043 (N.D. Me. 1978); see also Abalos v. Oil Dev. Co. of Tex., 526 S.W.2d 604 (Tex. Civ. App. 1975) (Ellis, C.J., dissenting) (finding a duty to intervene under section 321), affd, 544 S.W.2d 627 (Tex. 1976).

The Colorado appeals court decision in Leppke v. Segura, 632 P.2d 1057 (Colo. Ct. App. 1981), is of special note. The complaint in Leppke alleged that the defendants were negligent in helping an intoxicated person to jump-start his car, thereby enabling him to drive while under the influence of alcohol and to cause an accident that resulted in severe injuries to the plaintiff. The court concluded that the injuries were foreseeable consequences of the defendants' acts and that the lower court had erred in finding that 
The West Virginia case of Robertson $v$. LeMaster ${ }^{\mathbf{1 3 3}}$ is more closely analogous to the social-host problem. In that case, the defendant employer had forced his employee LeMaster to work twenty-seven hours without rest and then set him "loose upon the highway without providing alternate transportation or rest facilities."134 Allegedly as a result of his exhausted condition, LeMaster caused an accident and injured the plaintiffs. ${ }^{135}$ The trial court ruled that the defendant employer owed no duty to the plaintiffs, ${ }^{136}$ but the Supreme Court of Appeals of West Virginia disagreed. It concluded that the risk of the employee's dangerous driving was foreseeable to his employer, ${ }^{137}$ and further noted that the

negligent conduct . . . was not merely a failure to exercise appropriate precautionary measures, but includes an element of affirmative conduct in requiring LeMaster to work unreasonably long hours and then driving him to his vehicle and sending him out on the highway in such an exhausted condition as to pose a danger to himself or others. ${ }^{138}$

Although social hosts do not require guests to drink, and social pressures to drink differ from economic pressures to work, there is a clear parallel between Robertson and the social-host cases. In both instances, the driver's condition is a natural and foreseeable result of the host's or employer's actions, which the host or employer should realize have created a dangerous situation. Although a tired or intoxicated driver always has the option not to drive, in many cases her condition may be such that she does not recognize that option. The Robertson court did not suggest that the employer should have prevented the employee from driving; it did suggest, however, that the employer should have provided the employee with an alternative. ${ }^{139} \mathrm{~A}$ duty-to-intervene

there was no duty of care owed to the plaintiffs. The holding was based, however, on the duty to exercise reasonable care in carrying out an "affirmative act," embodied in section 320 of the Restatement. The court viewed this duty as quite distinct from liability based on a "failure to stop an individual who is already engaged in dangerous behavior," and likened the defendants' acts to "set[ting] into motion a force involving an unreasonable risk of harm to others." 632 P.2d at 1059.

133301 S.E.2d 563 (W. Va. 1983).

194 Id. at 567 .

135 See id. at 565 .

${ }^{136}$ See id. at 569.

${ }^{137}$ See id. at 568 .

$138 I d$. at $568-69$.

139 See id. at 568, 569 n.3. In Otis Eng'g Corp. v. Clark, 668 S.W.2d 307 (Tex. 1983), the Supreme Court of Texas held that the trier of fact should consider possible alternatives in determining whether an employer acted reasonably in sending a drunken employee home. Listed as alternatives were calling the employee's wife, sending him to. 
theory of liability for social hosts would impose the same duty on hosts with intoxicated guests.

\section{B. The Requirements of a Duty-to-Intervene Theory}

Both the duty to control another person's conduct ${ }^{140}$ and the duty to act when prior conduct is found to be dangerous ${ }^{141}$ require an actor to use "reasonable care."142 This standard, like that of the "prudent person," allows the factfinder to evaluate the defendant's conduct in light of the particular factual circumstances of the case. Thus, the dutyto-intervene theory gives a jury considerable discretion in measuring a host's actions against what a reasonably careful host might have done.

The duty-to-intervene theory requires a host to evaluate a guest's condition upon departure. If the guest appears to be too intoxicated to drive, the host can exercise any one of a number of options to prevent the potential danger. A host might warn the intoxicated guest that she is too drunk to drive, suggest that the guest stay for the night, suggest that the guest stay until she is sober enough to drive, drive the guest home, have someone else drive the guest home, or call a cab to take the guest home. ${ }^{143}$ The variety of responses to the situation seems to be limited only by the host's imagination. ${ }^{144}$

Certainly in most social-host situations at least one of the above alternatives would be feasible. Issues of feasibility, and the reasonable-

the nurse's aid station at the employer's plant, and having another employee drive him home. While this situation is different from Brockett, Robertson, and the typical socialhost case in that the employer in Otis did not help produce the employee's condition, the decision demonstrates some judicial willingness to find a duty to intervene. The court ruled that whether the employer had acted reasonably was a question for the jury. See id. at 311 .

140 See Restatement (Second) of ToRts $\S \S 315-19$ (1965).

141 See id. § 321.

142 See supra notes 89-93 and accompanying text; see also RESTATEMENT (SECOND) OF TORTS $\S 321$ (1965).

$143 \mathrm{By}$ analogy with situations involving physicians and dangerous patients, the host would clearly have a minimum obligation to warn the guest that she is too drunk to drive. See supra notes 100-04 and accompanying text. At the other extreme, whether liability is based on sections $315-19$ or section 321, the actions expected of a host would not include physical restraint of the guest; that requirement is usually not imposed even in cases involving dangerous mental patients. See supra notes 89-96 and accompanying text.

144 Bars have developed a variety of strategies to avoid liability. These solutions include paying the patrons' cab fares, sending a courtesy van to bring patrons to the bar and to drive them home again at the end of the evening, employing a service to drive intoxicated patrons to their homes, and encouraging groups of patrons to elect a "designated driver." See Caba, How the Bars Are Mixing Business and Responsibility, Philadelphia Inquirer, Sept. 23, 1984, at 1-A, col. 1. Some of these solutions are not economically feasible for social hosts, but they do provide ideas that social hosts can adapt to their particular circumstances. 
ness of a host's failure to intervene to prevent drunken driving, would be determined by the finder of fact. ${ }^{145}$ Liability would be imposed in cases in which the failure to intervene is deemed unreasonable.

\section{Advantages of the Duty-to-Intervene Theory}

Under conventional theories, a social host who wishes to avoid liability for an accident caused by an intoxicated guest has but one choice: to serve or not to serve. In contrast, a duty-to-intervene theory offers numerous alternatives to a host faced with the imminent departure of an intoxicated guest. ${ }^{146}$ This flexibility may appear to complicate the issue of liability; for instance, it is unclear whether a host must consider all conceivable means of intervention to demonstrate "reasonable care." The theory's flexibility, however, is actually desirable. Like other factoriented theories in tort law, the duty-to-intervene approach permits juries to consider a broad range of actions that may have been appropriate in a particular case.

A second advantage of the duty-to-intervene approach is that it is more equitable than conventional theories, which usually impose liability on a host who serves an already intoxicated guest but not on a host who causes a guest's intoxication. In either situation, the guest is equally likely to be a dangerous driver. The fact that the host who served an already intoxicated guest may have violated the state's alcohol-beverage-control law is irrelevant to an assessment of the danger created. A duty-to-intervene analysis holds both hosts liable by conditioning liability on the failure to stop an intoxicated guest from driving.

A third advantage of the proposed theory is that it does not require a host to refuse a guest a drink. Because liability hinges upon the failure to intervene rather than the service of alcohol, the host avoids the awkward situation of telling a guest that she will not be served any more alcohol.

A fourth advantage of the theory is that it does not require the host to monitor a guest's consumption of alcohol. In most social situations, such monitoring is burdensome, if not impractical. ${ }^{147}$ Under the duty-to-intervene theory, the host must evaluate a guest's sobriety only

145 See Otis Eng'g Corp. v. Clark, 668 S.W.2d 307 (Tex. 1983) (reasonableness of defendant's acts is a question for the jury). For example, in a case in which the host owned a car and the guest lived only a short distance away, the host might not be considered to have used reasonable care if the intoxicated guest were allowed to drive home.

${ }_{148}$ See supra note 143 and accompanying text.

147 See Kelly v. Gwinnell, 96 N.J. 538, 566, 476 A.2d 1219, 1235 (1984) (Garibaldi, J., dissenting) (guests frequently serve themselves or are served by other guests; it is difficult for a host to avoid serving a guest "on the brink of intoxication"). 
once-when the guest prepares to depart. This duty is much less onerous than the constant monitoring required by conventional theories.

Finally, imposing a duty on hosts to prevent their intoxicated guests from driving merely transforms into a legal duty what most people would consider common decency. Although many people would insist that they have a right to get drunk and to let their friends get drunk, fewer would insist that there is nothing wrong with knowingly allowing their guests to drive when the guests are so intoxicated as to be a danger on the roads.

\section{GoNCLUSION}

Imposing liability on social hosts for the acts of drunken drivers is consistent with the goals of the tort system, yet many courts are unwilling to hold hosts financially responsible in these situations. The dramshop acts, alcohol-beverage-control laws, and common-law negligence principles on which some courts have relied are unsatisfactory bases of liability. Their deficiencies include the unfairness of imposing liability on hosts who serve an already intoxicated guest while exempting those who render a guest intoxicated, as well as the problems created by requiring hosts to stop serving. intoxicated guests.

The duty-to-intervene theory of social-host liability proposed by this Comment can be seen as an extension of either of two common-law duties: the duty to control the conduct of another or the duty to intervene when prior conduct is found to be dangerous. Regardless of its basis, this theory would require hosts to evaluate the condition of their guests as they prepare to leave and to use reasonable care to prevent intoxicated guests from driving.

Those who would argue that the imposition of social-host liability is an inappropriate extension of existing tort doctrine should consider the case for social-host liability articulated by the New Jersey Supreme Court in Kelly v. Gwinnell: ${ }^{148}$

Does our society morally approve of the decision to continue to allow the charm of unrestrained social drinking when the cost is the lives of others, sometimes of the guests themselves?

If we but step back and observe ourselves objectively, we will see a phenomenon not of merriment but of cruelty, causing misery to innocent people, tolerated for years despite our knowledge that without fail, out of our extraordinarily high number of deaths caused by automobiles, nearly half 
have regularly been attributable to drunken driving. ${ }^{149}$

When put that way, the appropriateness of social-host liability seems perfectly clear. 